\title{
PROFESSOR CHRISTOPH VON FÜRER-HAIMENDORF
}

1909-1995

Professor Christoph von Fürer-Haimendorf, who died on 11 June 1995 at the age of 85, was Professor of Asian Anthropology at the School of Oriental and African Studies, where he built up the largest department of anthropology in the country by the time of his retirement in 1976. He was born in Vienna on 22 June 1909. Members of his family had served the Hapsburg dynasty since the year 1273 and one of them had been a famous traveller through Egypt, Palestine and Arabia in the early sixteenth century. His father held a senior position in the Austrian Civil Service, for a time as the Governor of Sudetenland, and the future anthropologist was brought up in a cultured atmosphere where he developed a passion for the surrogate travel afforded by the opera and for Indian classics, such as Tagore, which he read in his early adolescence.

In 1927 he entered the Theresianische Akademie of the University of Vienna to follow courses in anthropology and archaeology. In the 1920s in Vienna, anthropology was under the influence of the 'Kulturkrieslehre' school and under the direction of the linguist, Wilheim Schmidt, and the head of the Institute of Ethnology, Professor Koppers. The young Haimendorf was trained in anthropology by Schebesta and Frobenius; but the most lasting influence was exerted upon him by Professor Heine Geldern, whose archaeological research in South-East Asia inspired Haimendorf to choose the Naga hills of north-east India as the site for his first field-work. He received his Dr. Phil. in 1931, based on a doctoral thesis comparing the social organization of the hill tribes of Assam and north-west Burma. However, for financial reasons, his thesis was based purely on book research - the opportunity for field-work came only later with funds from the Rockefeller Foundation, when Haimendorf worked as a Research Assistant in Vienna between 1931 and 1934. Being primarily interested in India, he decided to forgo the opportunity of studying in America in favour of the London School of Economics, where he hoped to attend the famous seminars of Bronislaw Malinowski, and was to meet many future British anthropologists, such as Raymond Firth and Audrey Richards. Although intellectually stimulated and inspired by Professor Malinowski, Haimendorf was not uncritical of the recommended functional approach, and he left London in 1936 to work among the Nagas of Assam, along the northeastern frontier of India.

Upon arrival, Haimendorf was helped greatly by both the District Officers and the anthropologist J.P. Mills, the then Deputy Commissioner of the Naga Hills District, who soon became a close friend. Together they departed on a punitive expedition to the unadministered tribal areas which lay between the Naga Hills and the frontier of Burma where there had been a recent spate of tribal raids. They were accompanied by two platoons of the Royal Assamese Rifles as well as several hundred coolies, and survived a serious ambush to return with a number of dried skulls as trophies for the delighted Nagas. Although he had studied Assamese whilst in London at SOAS, it was only during this first expedition with Mills that Haimendorf became convinced of the importance of linguistic competence for successful ethnography. After only five months among the Nagas, he managed to acquire enough Nagamese to dispense with his interpreter.

After 13 months of field-work, Haimendorf returned to Austria but soon 
left again for India, and was en route to the Naga Hills for a second period of research when the Second World War broke out. Being in possession of a German passport, he was arrested by the authorities - albeit with great courtesy due to his excellent connections in the British colonial administration - and was promptly interned as an enemy alien. He was subsequently confined to Hyderabad State, under the jurisdiction of the Nizam, but was able to undertake some of his best field-work among such groups as the Chenchus, Reddis and Raj Gonds. Many of the tribal populations that Haimendorf researched at this time were little known and poorly described, and the Chenchu gather-hunters provided him with a point of contrast and comparison to the splendidly decorated Nagas. In his fourth year of stay in Hyderabad, he was curiously offered the post of Special Officer and Assistant Political Officer to the North East Frontier Agency, and was thereby permitted to do field-work among the remote and warlike Apa Tanis of the Arunachal Pradesh area of Assam. Although the brief of his official position was to monitor the security threat posed by the partial occupation of neighbouring Burma by Japan, the posting really afforded Haimendorf the opportunity of conducting in-depth field-work for two whole years, 1944 and 1945.

At the end of the war, Haimendorf was appointed to the position of Advisor for Tribes and Backward Classes to the Nizam's Government of Hyderabad to deal with the complicated issue of land reform. In the course of his work, he set up various educational and other schemes for tribal peoples, all with the aim of preserving and safeguarding indigenous cultures and languages. He also accepted a teaching appointment at Osmania University which he later relinquished, after ten years in India, to accept a lectureship at the SOAS in 1949. Within months of his initial appointment, he was made Reader, and then Chair of Asian Anthropology in the School in 1951. During his 25 years as Professor, until his retirement in 1976, Christoph von FürerHaimendorf saw the department through a period of quite exceptional growth, always encouraging his staff and students to conduct field-work as frequently and intensively as possible. His standing in the School was reflected in his appointment as Acting Director for the academic session 1969-70 while the then Director, Professor (Sir) Cyril Philips served as Vice-Chancellor of the University of London.

In 1953, on a trip back to the Gonds of Andra Pradesh, the Kingdom of Nepal was officially opened to outsiders and Professor Haimendorf took the opportunity to visit the country and thereby added a third area of expertise to Assam and Hyderabad. In each area he studied the languages and culture of between three and six societies. He published ten ethnographic monographs based on his field-work, including The Chenchus (1943), The Reddis of the Bison Hills (1945), The Raj Gonds of Adilibad (1948), The Sherpas of Nepal (1964) and The Konyak Nagas (1969). He also published several other volumes of essays and theoretical works, including Morals and merit (1967) and The tribes of India: struggle for survival (1982), which drew heavily on his field-work.

For over forty years Professor Haimendorf travelled, filmed and wrote extensively on the peoples of the Central and Eastern Himalayas and Central India. It is difficult to think of any other European anthropologist who could rival his 3650 pages of published ethnography describing a dozen tribal groups. $\mathrm{He}$ was the first foreign anthropologist to be allowed to work in Nepal. He was at first drawn to the Sherpas of Eastern Nepal, partly because of their reputation in the scaling of Everest, but more particularly because of the stark contrast they provided in terms of religion and culture to the populations of tropical India with whom he had been previously occupied. Until the 
mid-1960s, Haimendorf concentrated almost exclusively on Nepal, during which time he walked the length and breadth of the country, often in the company of Dor Bahadur Bista, noting down what he saw and encouraging his students to return to these areas for more detailed study.

The published work is only the surface of his achievement. As well as his meticulous and detailed field-notes and diaries, he was one of the only anthropologists of the great inter-war generation in Britain to realize the importance of visual documentation. His collection of black-and-white photographs extend to over 10,000 separate photographs, capturing memorably many aspects of tribal culture. They were accompanied by an equal number of colour slides, documenting worlds which have since changed beyond recognition. He was also one of the most prolific of British ethnographic film-makers, starting to film in the 1940s and shooting over 100 hours of $16 \mathrm{~mm}$. films, a number of which were used for $\mathrm{BBC}$ television documentaries, such as The land of the Gurkhas (1957) and The land of Dolpo (1962). He made many hundreds of hours of tape recordings to accompany the films. He also made extensive collections of artefacts for the anthropology museums at Vienna, Cambridge and elsewhere.

A number of factors help to explain his ability as an ethnographer. There was his curiosity; he was clearly immensely interested in people, in exploring, in wanting to know and understand and then to move on to a new encounter. There was his aesthetic ability and appreciation of beauty, which lay behind his photography and his delight in the graceful peoples with whom he worked. There was his photographic memory combined with self-discipline, which filled his notebooks and diaries with thousands of pages of vivid and illuminating comment. There was his obvious sympathy for tribal peoples and their increasingly difficult position. And there was his linguistic flair and his intelligence.

He received numerous academic honours. As well as the Sykes and Roy Medals, he was awarded the RAI Rivers Memorial Medal in 1949, and was President of the Royal Anthropological Institute itself from 1975 to 1977 . He was specially pleased to be awarded the King Birendra Prize by the Royal Nepal Academy in 1976 and the Austrian Order of Merit for Art and Science in 1982. However, the most immediate prizes in academic life go to those who engage in abstract theory. While he put forward some exciting ideas, particularly on morality and religion in his Frazer Lecture on "The after life in Indian tribal religions' and his Henry Myers Lecture on 'The sense of sin in crosscultural perspective', his main interest was in understanding and describing how societies work. Good field-work and writing ethnographic texts require a special form of intelligence which he showed in large measure, as well as a genuine skill which is different from comparative theoretical work, but equally difficult. Haimendorf's great ability to make friends and to manage human relationships, especially in difficult situations, won him the trust of both Europeans and his many non-European co-workers and colleagues. In all this he depended very heavily on his wife Betty Barnado, whom he married in 1938 - co-worker, organizer of his expeditions, inspiration and herself a notable ethnographer. His own autobiography was a tribute to her, published in 1989 in his eightieth year, with long excerpts from her diaries and a moving account of her death.

The four thousand pages of published ethnography, the unpublished notes and diaries, the photographs and films provide invaluable insights into a number of tribal worlds. Haimendorf had the sense, energy and ability to record for posterity a little of what is now lost. When many smaller peaks 
have faded from view, his work and life will stand out as one of the major ethnographic contributions of all time.

Professor Haimendorf bequeathed his whole collection and opus to SOAS. At present, with the collaboration of staff of the Department of Social Anthropology at Cambridge, the School is collating and preparing a complete archive which will include as much of the written work, films and still photographs as possible. The archive will be lodged in the School Library and it is hoped that it will serve as a rich research resource for all those with an interest in the areas Professor Haimendorf visited. It will also exist as a testament to the achievements of a great man.

As a person, Christoph von Fürer-Haimendorf was courteous, genial, charming and extremely personable, with a wide circle of friends. After anthropology, his second love was the classical music of his native Austria, which helped to give him solace in old age though he was never reconciled to modern styles of opera production.

Most of his colleagues were unaware that he was a committed Catholic who went to Mass every Sunday when in London. After Betty's death in 1987, he suffered a slow and distressing decline. His Requiem Mass at the Carmelite Church in South Kensington on 23 June last year included an address by his successor at the School of Oriental and African Studies, Professor Adrian Mayer; a translation of the song 'Happy we are' written by Gond villagers about the return of the Haimendorfs and read by his grandson, Max, and superb choral renderings of Bach and Mozart.

Alan MacFarlane and Mark TURIN Department of Social Anthropology, Cambridge

[An earlier version of this Obituary was published in Anthropology Today, Vol. 11, no. 4, 1995.] 